\title{
Anti-aging effects of the proteins from artemia extract on human fibroblasts cell proliferation and collagen expression in induced aging conditions
}

\author{
Neda Vaseli-Hagh ${ }^{1}$; Abdolkhaleg Deezagi*1; Mahvash Khodabandeh Shahraki \\ ${ }^{1}$ Department of molecular medicine \& Biochemistry, National Institute of Genetic Engineering and Biotechnology, Tehran-Iran. \\ ${ }^{2}$ Department of Technology \& Environment, National Institute of Genetic Engineering and Biotechnology, Tehran-Iran
}

\author{
*Corresponding Author(s): Abdolkhaleg Deezagi \\ Department of Biochemistry, National Institute of \\ Genetic Engineering and Biotechnology, Km. 17, \\ Karaj-Tehran freeway, Pajouhesh Blvd. P.O. Box \\ 4798110872, Tehran-IRAN
}

Tel: 0098-21-44580377, Fax: 0098-21 44580399;

Email: deezagi@nigeb.ac.ir

Received: Aug 29, 2018

Accepted: Oct 02, 2018

Published Online: Oct 05, 2018

Journal: Annals of Biotechnology

Publisher: MedDocs Publishers LLC

Online edition: http://meddocsonline.org/

Copyright: CDeezagi A (2018). This Article is distributed under the terms of Creative Commons Attribution 4.0 International License

Keywords: Anti-aging; Artemia extract; Collagen type I; Human fibroblasts; Cell senescence

\section{Introduction}

Aging and senescence are characterized by the reduction of response to stress, increasing homeostatic imbalance and increased risk of diseases [1]. Many factors such as genetic elements, free radicals, oxidants, Reactive Oxygen Species (ROS), telomeres shortening, alcohol and etc. influence and related to aging $[2,3,4]$. In replicative senescence, normal somatic cells invariably enter a state of irreversibly arrested growth and altered function after a finite number of divisions [5]. Evidences indicated that, this process is related to a tumor-suppressive mechanism and an underlying cause of aging [6].

\section{Abstract}

Researches on the factors that inhibit senescence are attractive in health industries. Artemia extract uses in cosmetic and sunlight protecting products. The aim of this work was to study the effects of Artemia extract on the cell proliferation, senescence and collagen synthesis by human fibroblasts in normal and aging induced conditions. Artemia extract was extracted from napauliies and partially purified in 7 fractions. The human foreskin fibroblasts (normal and $\mathrm{H}_{2} \mathrm{O}_{2}$ stressed) were treated by crude and/or fractions in a dose dependent manner for $96 \mathrm{~h}$. Cell counting, MTT and BrdU assays indicated that the fractions $4,6,7$ induce cell proliferation. Treatment of cells by these fractions resulted in the reduction of senescence-associated ß-Galactosidase activity up to $50 \%$ in comparison to $\mathrm{H}_{2} \mathrm{O}_{2}$ treated control cells. The highest collagen type I mRNA expression was observed in fractions 5 and 7 . The mRNA level increased in comparison with untreated and house keeping gene ( $\beta$-actin) mRNA level. Percent of collagen type I expression to $\beta$-actin was 2.19 and 1.31 fold in cells which treated by fractions 5 and 7. Artemia extracts induce fibroblast proliferation, collagen synthesis and reduce cell senescence. These finding support the anti-aging effect of this product for probable application in the future.
In hemostasis some anti-aging factors, such as ascorbate, tocopherol and carotenoids neutralize aging inducing factors. These factors defenses against oxidative damages. Compounds from marine sources have been reported to have bioactive properties with varying degrees of actions such as anti-tumor, anticancer, anti-microtubule, anti-proliferative, anti-hypertensive, cytotoxic and antibiotic properties $[7,8,9]$. Researches on the new anti-aging factors that inhibit senescence are interesting option in cell biology, cosmetic production and health industries $[10,11,12]$. Artemia extract uses in cosmetic and sunlight pro-

Cite this article: Vaseli-Hagh N, Deezagi A, Shahraki MK. Anti-aging effects of the proteins fromartemia extract on human fibroblasts cell proliferation and collagen expression in induced aging conditions. Ann Biotechnol. 2018; 3: 1015. 
tecting products. Evidence indicated that the artemia extract contains tetra phosphate. Artemia uses it as energy source. $\mathrm{P}$ 26 protein from artemia possesses molecular-chaperone activity for RNA [13]. Artemia extract contains biologically active substances that cause increase in metabolism of skin cells and epidermal cell proliferation too. These evidences indicated that, artemia extract can provide anti-aging effects on cells and also harmonize with other anti-aging agents. Artemia found in a wide variety of hyper saline habitats ranging from desert to, tropic toand mountains. Artemia encysted and diapause exhibits a level of stress tolerance such as hyper salinity, very low oxygen tensions and extreme of temperature [14]. One of this species (Artemiaurmiana) lives in lake of Urmia in Iran. Lake of Urmia is one of the largest permanent hypersaline lakes in the world and resembles the great salt lake in the western USA in many respects of morphology, chemistry and sediments $[15,16]$.

Mud of the Urmia lake and Artemia urmiana extract have been used in traditional medicine to treatment of skin inflammatory disorder The properties of Urmia Lake water and biomaterials derived from its organisms make it suitable for the treatment of various rheumatism diseases, skin disorders, metabolic disorders, women's diseases, and so on. The mud of this lake is black in color and have a boosting effect. The high concentration of salt in the lake also makes the floating on the water bring it relaxation to the individual. Skin collagen and joint diseases are also treatable with artemia extract, black mud and salt. Among other therapeutic properties of Urmia lake living organisms, treatment of respiratory diseases such as asthma and bronchitis and various sinusitis can also be mentioned. Urmia Lake water is one of the watersheds of Sodium chloride. Drinking this water reduces bile concentrations and as a result, bile secretion improves better [17]. The extract uses in cosmetic and health industries. Literature review indicates that the content and mechanism of action of its'active materials poorly studied. Therefore the aim of this work was to evaluate the anti-aging effect of artemia extract in cellular level in vitro. For these purposes; we isolate and purified the proteins of $A$. urmiana extract. The effects of partially purified proteins on the cell growth, senescence and collagen type I expression of human foreskin fibroblasts were studied.

\section{Materials and methods}

All chemicals which used in this study were provided from Merck (Merck, Darmastd, Germany) except which indicated from other sources otherwise and separately.

\section{Cyst hatching}

A. urmiana cysts were provided from Urmia lake (west-north of Iran). $10 \mathrm{gr}$ of cysts were hydrated in water at room temperature for one hour. Then the cysts were decapsulated by Sodium Hypocholorate $(\mathrm{NaOCl} 2.5 \%)$ for 2-3 min to change the colure of cysts from brown to orange. Then the cysts were washed by 500 $\mathrm{ml}$ of cold distilled water. The encapsulated cysts were hatched in 2 liters of artificial sea water (0.4 M NaCL , $0.009 \mathrm{M} \mathrm{KCL}, 0.05$ $\mathrm{M} \mathrm{MgCL} 2,0.009 \mathrm{M} \mathrm{CaClL}_{2}$ and $0.028 \mathrm{M} \mathrm{Na}_{2} \mathrm{SO}_{4^{\prime}} \mathrm{pH}=8.0$ ) according the method reported by Rottini [18]. The cysts were incubated at $28^{\circ} \mathrm{C}$ for $24 \mathrm{hr}$ under light chamber in a shaking incubator. Freshly hatched napulii are phototropism, therefore they were collected by attraction to light). The collected napuliies were washed with $400 \mathrm{ml}$ of cold distilled water. Embryos were suspended in $50 \mathrm{ml}$ of stock solution of $A$ [19] $\mathrm{pH}=7.6$ and sonicated three times for 30 second. Then stock solution of $B(1 / 9)$ was added and centrifuged at $20000 \mathrm{~g}$ for 20 minutes (Heraeus,
Hanau, Germany). The supernatants were filtered through two layers of Mira cloth. The filtered homogenate was keep at $-200 \mathrm{C}$ for protein purification. In all of experiments total protein concentration was measured by modified Bradford methods [20]. The proteins content of crude extracts was precipitated with salt extraction by using Ammonium Sulfate $40 \%(\mathrm{~W} / \mathrm{V})$ at $4^{\circ} \mathrm{C}$ by shaking for $2 \mathrm{hr}$. The precipitate was centrifuged at $5000 \mathrm{rpm}$ for 20 minutes (Heraeus, Hanau, Germany) for $20 \mathrm{~min}$ at $4^{\circ} \mathrm{C}$. Then the pellet was dissolved in dialysis buffer (Tris- $\mathrm{HCl} 50 \mathrm{mM}, \mathrm{pH}$ 8.7) and dialyzed against the same buffer for 24 hrsat 4 으 by 2 times change of the buffer.

\section{DEAE-Sepharose anion-exchange chromatography}

A $18 \times 3 \mathrm{~cm}$ DEAE Sepharosecolumn (What man, Maidste, England) was used for chromatography. First, the column was extensively washed by binding Tris buffer (Tris-Base $50 \mathrm{mM}, \mathrm{pH}$ 7.5) for equilibration. Subsequently, protein was eluted applying elution buffer $(100 \mathrm{ml}$ of Tris-Base $50 \mathrm{mM}, \mathrm{pH}$ 7.5). Then salt gradient was applied by adding $400 \mathrm{ml}$ of 0.1 to $1.0 \mathrm{M}$ of $\mathrm{NaCl}$ in Tris-Base $50 \mathrm{mM}$ buffer $\mathrm{pH} 7.5$ by flow rate about $1 \mathrm{ml} /$ $\mathrm{min}$. Each $3.0 \mathrm{ml}$ of samples was collected and monitored at 280 $\mathrm{nm}$ continuously. The samples of each fraction were collected together and dialyzed. The final total protein concentration was measured by modified Bradford methods. Finally, the fractions were concentrated and sterilized by $0.2 \mu \mathrm{m}$ filter papers (What man, Mailste, England) to use for further analysis in cell culture system.

For analysis of the proteins profile, crude extract and different fractions of chromatography were electrophoresedon $13 \%$ resolving SDS-PAGE gel based on the buffers used by Laemmeli [21]. The electrophoresis was done by LKB-Pharmacia electrophoresis system (LKB Pharmacia, Uppsala, Sweden). After running; the gels were stained by coomassie blue.

\section{Human foreskin fibroblast isolation and culture}

Primary human fibroblasts cells were isolated from human neonatal foreskins by inform and consenting donors. As the donors were neonates, written, informed consent was obtained from the legally authorized parents of the donor neonates for using foreskin surgery tissuesat the Mustafa Khomeini hospital prior to the study. In order to isolate fibroblasts, the other intruding peripheral tissues were removed. The tissue was chopped in 2-3 mm dissected into small sections. These small fragments were incubated in the collagenase solution $(1.1 \mathrm{U} /$ $\mathrm{ml}$ ) (Gibco, Paisley, United Kingdom) at $37^{\circ} \mathrm{C}$ for $50 \mathrm{~min}$. The mixture was centrifuged (300xg for $5 \mathrm{~min}$ at $4{ }^{\circ} \mathrm{C}$ ). The cells were cultured in dulbecco's modified eagle's medium (DMEM) supplemented by $10 \%$ fetal bovine serum (FBS) (Gibco, Paisley, United Kingdom). Cultures were maintained at $37{ }^{\circ} \mathrm{C}$ with a humidified atmosphere of $5 \% \mathrm{CO}_{2}$. Culture media were changed twice a week until the culture density reached to $80 \%$ confluency. Then, the cells were trypsinized and passaged regularly. In all experiments, cells in passages 4 to 6 were used for treatment study.

\section{Oxidative stress induction of cells by $\mathrm{H}_{2} \mathrm{O}_{2}$ and later treat- ment by artemia extracts}

Primary human fibroblasts $\left(3 \times 10^{4} \mathrm{cell} / \mathrm{s} / \mathrm{cm}^{2}\right.$ in DMEM) were separately treated by $\mathrm{H}_{2} \mathrm{O}_{2}(6.5 \mu \mathrm{M})$ for $2 \mathrm{hr}$. Then the cells were washed and treated by increasing concentration of artemia extract $(0,5,25,50,100 \mu \mathrm{g} / \mathrm{ml})$ in $5 \mathrm{~mL}$ of DMEM medium containing $10 \%$ of FBS in 6-wells plates (Nunc, Roskilde, Denmark). The cells were incubated at $37^{\circ} \mathrm{C}$ for $72 \mathrm{~h}$. Then the cells and 
supernatant of the treated cells were collected separately. The effect of artemia extracts on the cell growth, cell proliferation, cell senescence and expression of human Collagen type Iwere done as describe below.

\section{BrdU and MTT cell proliferation assay}

In order to examine the effect of artemia extract on the cell growth and cell proliferation, the cells were collected after $72 \mathrm{~h}$ of treatment and the total cell number, cell viability, Bromodeoxyuridine (BrdU) and MTT cell proliferation assays were done. The cell number and viability were enumerated using a Neubauer hemocytometer. BrdU cell proliferation assay was done using the BrdU cell proliferation ELISA kit (Roche, Mannheim, Germany) according to the manufacturer's instructions. Briefly $3 \times 10^{3}$ cells (in $100 \mu \mathrm{l} /$ well) of control and treated cells were transferred to 96-well micro titer plate. $10 \mu \mathrm{l}$ of BrdU solution was added to each well and incubated over night. Then the micro wells were centrifuged and dried by hair drier. $200 \mu \mathrm{l}$ of Fix Denat was added to each well and incubated for $30 \mathrm{~min}$ at $15-25^{\circ} \mathrm{C}$. After removing of FixDenat, $100 \mu \mathrm{l} /$ well of anti-BrdUperoxidase conjugated antibodies were added and incubated for $90 \mathrm{~min}$ at room temperature. The solution was completely removed and the wells were washed three times with $200 \mu \mathrm{l}$ of washing buffer. Finally, $100 \mu$ l of tetramethylbenzidine (TMB) substrate solution was added and incubated at room temperature for $15 \mathrm{~min}$ and reaction was stopped by adding $100 \mu$ of stop solution. The absorbance were measured at $550 \mathrm{~nm}$ by ELISA reader (Labsystems Multiskan, Roden, Netherlands). In MTT assay, $3 \times 10^{3}$ untreated and treated cells (in $100 \mu \mathrm{l} /$ well) were transferred to flat bottom 96 micro titer plates. Then $10 \mu \mathrm{l}$ of freshly prepared [3-(4,5-dimethylthiazol-2-yl)-2, 5-diphenyltetrazolium bromide] (MTT) (Sigma, St. Louis, MO, USA) solution (5 $\mathrm{mg} / \mathrm{ml}$ in PBS) was added to each well and were incubated for $4 \mathrm{~h}$. Finally, supernatant removed then $50 \mu \mathrm{l}$ of DMSO solution was added to each well. Absorbance was read at $580 \mathrm{~nm}$ using an ELISA reader (Labsystems Multiskan, Roden, Netherlands).

\section{Senescence sensitive $\beta$-galactosidase staining}

Cytochemical staining for acidic senescence associated $\beta$-galactosidase (SA- $\beta$-gal) was performed as described by Gary and Kindell with some modification [22]. Briefly treated cells by $\mathrm{H}_{2} \mathrm{O}_{2}$ and/or artemia extract were collected and washed by PBS. Then the cells were fixed for 3-5 $\mathrm{min}$ in a fixative ( $2 \%$ formaldehyde, $0.2 \%$ glutaraldehyde in PBS). The the cells were incubated for $12 \mathrm{hr}$ at $37^{\circ} \mathrm{C}$ with freshly prepared $\beta$-galactosidase staining solution: $1 \mathrm{mg} / \mathrm{ml}$ of 5-romo-4-Chloro-3-Indolyl- $\beta$-DGalactopyranose (X-Gal) (Sigma, St. Louis, MO, USA), 20mg/ $\mathrm{ml}$ of dimethylformamide, $40 \mathrm{mM}$ citric acid/sodium phosphate, pH 6.0, $5 \mathrm{mM}$ Potassium Ferrocyanide, $5 \mathrm{mM}$ Potassium Ferricyanade, $150 \mathrm{Mm} \mathrm{NaCl}, 2 \mathrm{mM} \mathrm{MgCl}$. Finally, the substrate was collected and the cells were washed. The absolute of blue stained cells was observed directly by eye microscopy and percent of stained cells were counted in minimum of 300 cells.

\section{Semi-quantitative detection of collagen type I by RT-PCR}

Artemia extract treated fibroblasts were collected and total RNA was extracted by using the tripure isolation reagent (Roche, Mannheim, Germany), according to the manufactures protocol. RNA yield and purity were quantities by measuring optical density $\left(\mathrm{OD}_{260 / 280}\right)$ using a spectrophotometer Beck man DU530 (Beckman Coulter Inc. CA, USA). First-strand cDNA was synthesized from $1 \mu \mathrm{g}$ of total RNA using Maurine Maloney Leukemia virus (M-MLV, Fermentase) and reverse transcriptase
(Fermentase Gmbh, Leon-Rot, Germany) with oligo-dT primer (Fermentase Gmbh, Leon-Rot , Germany), according to the manufacturer's instructions. The collagen type I cDNA and $\beta$-actin cDNA were amplified by the following primers:

Collagen type I forward primer:

\section{5'CCCCCTCCCCAGCCACAAAG-3'}

Collagen type I reverse primer:

\section{5'-TCTTGGTCGGTGGGTGACTCT-3'}

\section{$\beta$-actin forward: 5'-AAGAGAGGCATCCTCACCCT-3'}

$\beta$-actin reverse :5'-TACATGGCTGGGGTGTTGAA-3'.

The expected sizes of the PCR product were 360bp for collagen and $220 \mathrm{bp}$ for $\beta$-actin. The thermal cycling conditions for amplification of collagen and $\beta$-actin fragments were as follows: $94^{\circ} \mathrm{C}$ for 5 min., followed by 35 cycles at $95^{\circ} \mathrm{C}$ for $60 \mathrm{~s} ; 56^{\circ} \mathrm{C}$ for $60 \mathrm{~s} ; 72^{\circ} \mathrm{C}$ for $90 \mathrm{~s}$. This was followed by re-extension at $72^{\circ} \mathrm{C}$ for $10 \mathrm{~min}$. The PCR products were separated on a $1.8 \%$ agarose gel (using $0.5 \times$ TBE buffer) and visualized by ethidium bromide staining.

\section{Statistical analysis}

Each experiment was minimally performed three times for all data, each carried out in duplicated sequences. Data were analyzed using a One-Way Analysis of variance (ANOVA) Values were given as the mean \pm Standard Deviation (SD) and analytical variables were compared by using the students' t-test. By convention, a $\alpha$-level of $p<0.05$ was considered to be statistically significant

\section{Results}

\section{Protein extraction and purification}

Freshly isolated napuliies were collected, and suspended $(0.2$ $\mathrm{gr} / \mathrm{ml}$ ) in extraction buffer. The amounts of extracted proteins were about $17.6,40.6$ and $16(24.7 \pm 13.7) \mathrm{mg} / \mathrm{gr}$ of napuliies wet weight respectively. SDS-PAGE electrophoresis was done for analyses the protein profile of crude extract (Figure 1).

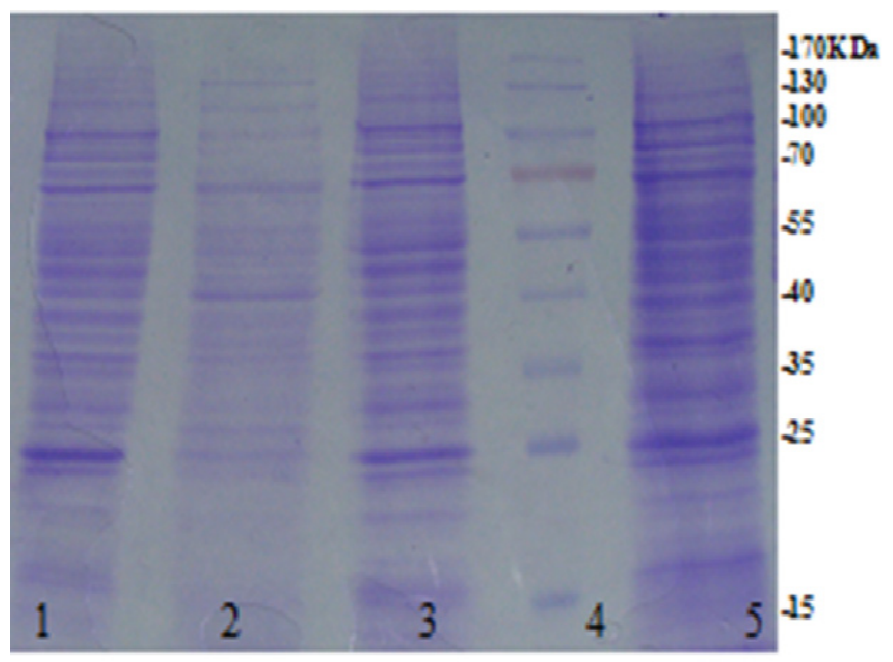

Figure 1: The SDS PAGE of A. urmiana extract. Crude extract was electrophoresed on $13 \%$ resolving SDS-PAGE gel. Line 1,3,5 indicated protein pattern of napaullies after $18 \mathrm{~h}$ of hatching. Line 2 indicated protein pattern of napaullies after $24 \mathrm{~h}$ of hatching. Line 4 protein MW marker. 
Partial purification was done by DEAE sepharose ion exchange chromatography as described in methods. The samples were collected andmonitored at $280 \mathrm{~nm}$ continuously. Figure $2 a$. indicated to the chromatogram of the purification. Seven obvious fractions (1-7) were observed in the chromatogram. The fractions 1 and 2 belong to the cationic proteins which didn't bind to DEAE resin. Fractions 3, 4, 5, 6 and 7 resulted to the salt gradient elution of $0.1,0.2,0.3,0.4,0.5$ and $1 \mathrm{M}$ of $\mathrm{NaCl}$. Different fractions of chromatography were electrophoresed on $13 \%$ resolving SDS-PAGE gel (Figure $2 \mathrm{~b}$ ). The purified fractions were filtered by $0.22 \mu \mathrm{m}$, concentrated by freeze-drying and used for treatment and studying of anti-aging effects on fibroblasts.
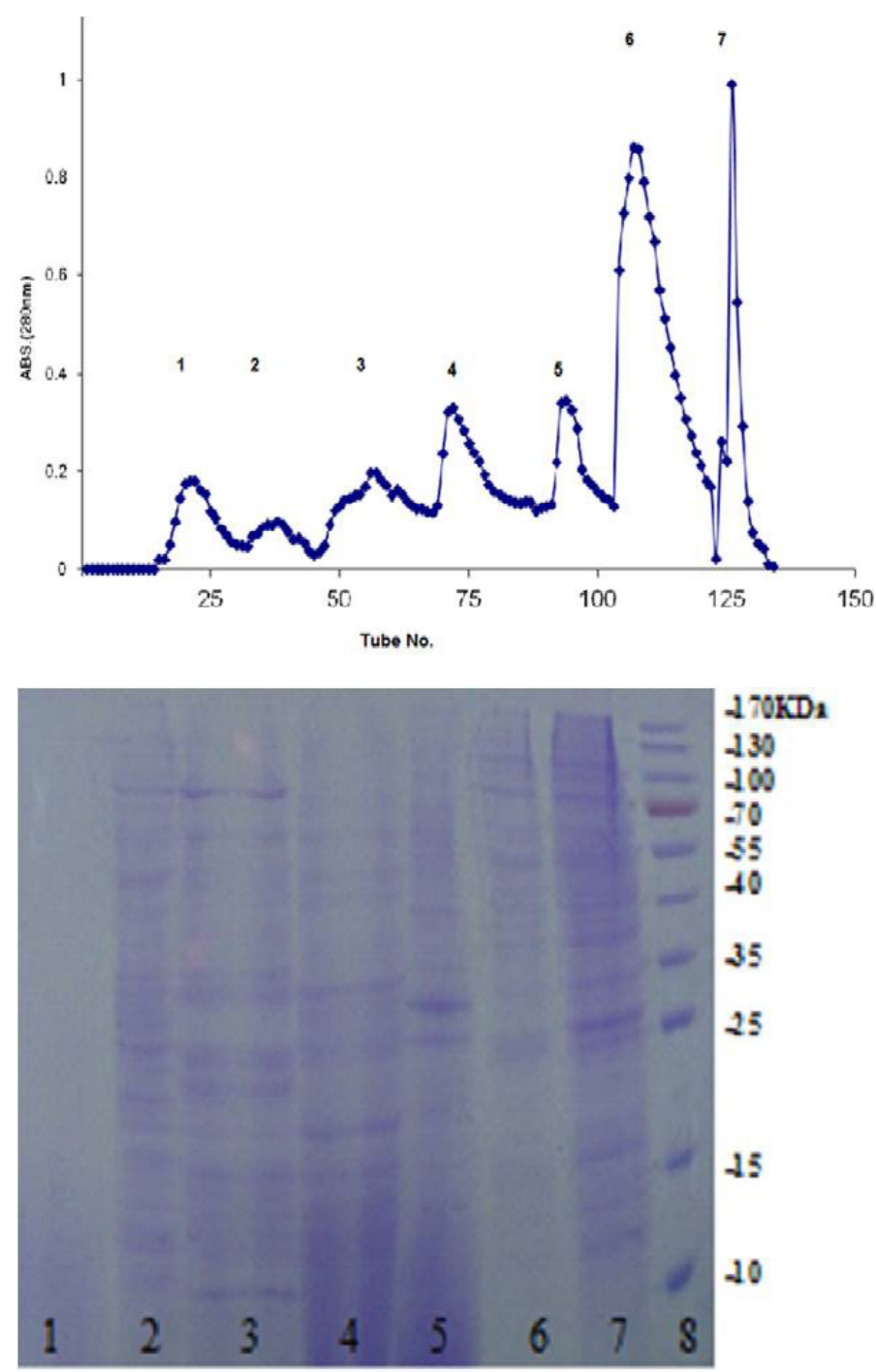

Figure 2: The chromatogram of DEAE anion exchange chromatography of Artemia extract and SDS-PAGE electrophoresis of the purified fractions. a) Chromatogram of the chromatography; fractions 1 and 2 belong to the cationic proteins, fractions 3, 4, 5, 6 and 7 resulted to the salt gradient elution of $0.1,0.2,0.3,0.4,0.5$ and $1 \mathrm{M}$ of $\mathrm{NaCl}$. b) Different fractions of chromatography were electrophoresed on 13\% resolving SDS-PAGE gel. Line1-7 are samples from fractions 1-7 respectively, line8is prestained protein ladder SM0671 fermentase

\section{Cell proliferation}

The effects of artemia extracts (crude extract and 7 fractions after chromatography) on cell proliferation in normal and stressed condition were assayed as described in methods.The values for each testwere averaged and growth curves were constructed. Results indicated that fractions 3,5 and 6 increased cell proliferation in comparison to untreated cells and artemia crude extract treated cells by MTT assay (Figure 3a). Fractions 4, 6 and 7 showed increase in BrdU incorporation and entrance of cells to $S$ phase of cell cycle in comparison to cells treated by crude extract and control cells (Figure $3 b$ ). Results indicated to increasing of cell growth potential and cell proliferation parameters up to $40 \%$ in the presence of artemia extract fractions $(3,4,5,6,7)$ in comparison with untreated control cells.
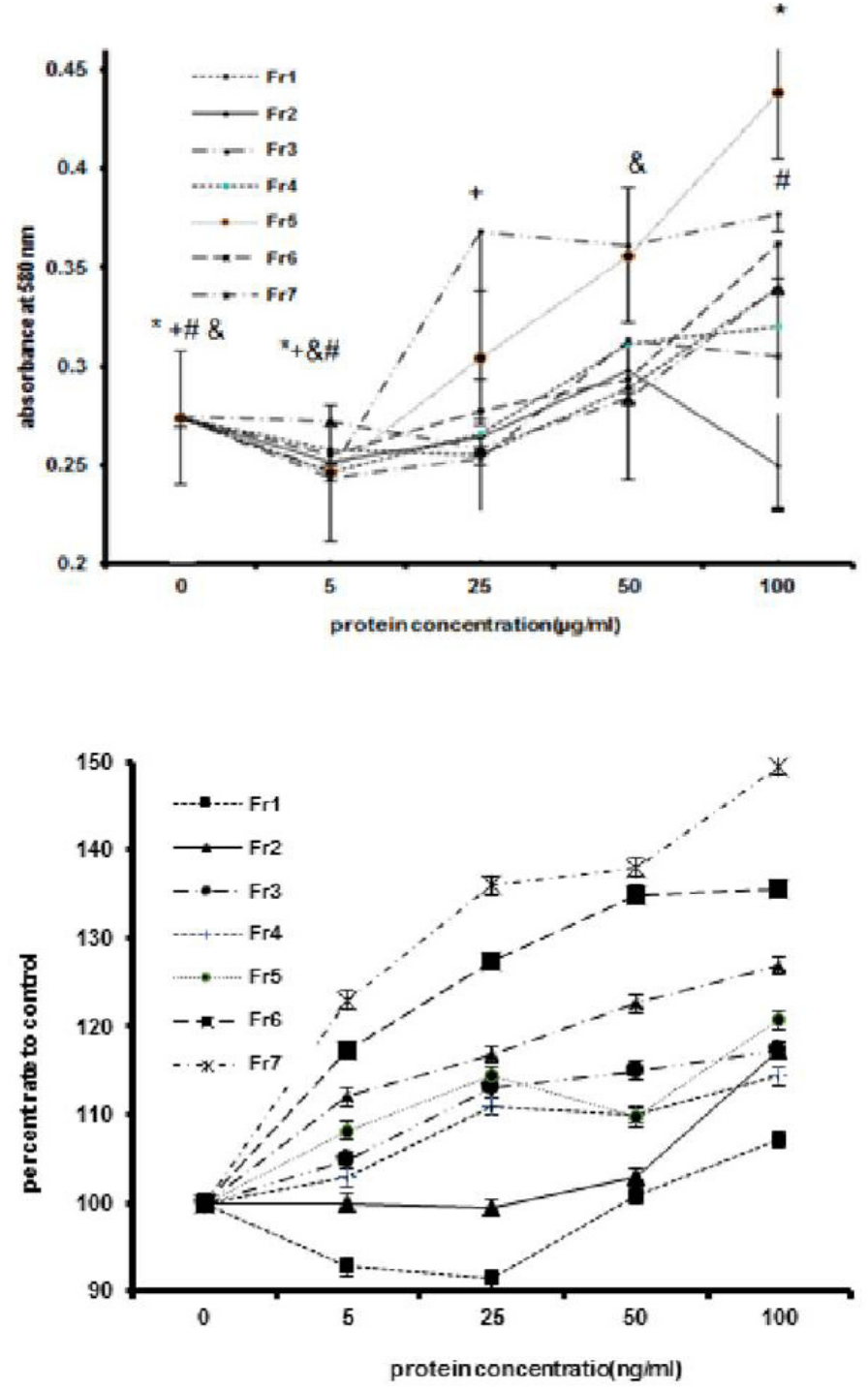

Figure 3: The effect of Artemia extract and purified fractions on the cell growth and cell proliferation of human fibroblasts by BrdU and MTT assay. The cells were grown in DMEM medium in the absence or presence of different concentrations of artemia extract purified proteins for $72 \mathrm{~h}$ as described in "Materials and Methods". At the time point, control and treated cells were collected: a) MTT assay of artemia extract and partially purified fractions. b) BrdU cell proliferation assay. The results are mean \pm S.E.M. for three separate experiments.+, $\boldsymbol{\&}, *$ indicated to the significance of the concentrations of 25,50 and $100 \mu \mathrm{g} / \mathrm{ml}$ of fraction 7 in comparison to untreated control cells and cells treated by $5 \mu \mathrm{g} / \mathrm{ml}$ of fraction 7 ( $p<0.01)$. \# indicate to significance of the concentrations of 100 $\mu \mathrm{g} / \mathrm{ml}$ of fraction 6 in comparison to untreated control cells and cells treated by $5 \mu \mathrm{g} / \mathrm{ml}$ of fraction $6(p<0.01)$. 


\section{Senescence sensitive $\beta$-Galactosidase staining}

The cells (normal and $2 \mathrm{hr} \mathrm{H}_{2} \mathrm{O}_{2}$ stressed conditioned fibroblasts) were incubated with Artemia extract for $72 \mathrm{hr}$ and assayed for $\beta$-Galactosidase activity as described in methods. Light microscopy confirmed the slightly inhibition of senescence with typical features of senescence. These features include an increased cell size and cytoplasmic granularity in blue stained senescence cells in comparison to untreated cells (Figure 4a). The stained cells were counted and the percent of stained cells were calculated (Figure $4 \mathrm{~b}$ ). The results showed that the addition of artemia extract (fractions 5, 6 and 7) reduced the number of senescence $\beta$-Galactosidase positive cells up to $50 \%$ in comparison to $\mathrm{H}_{2} \mathrm{O}_{2}$ treated control cells.
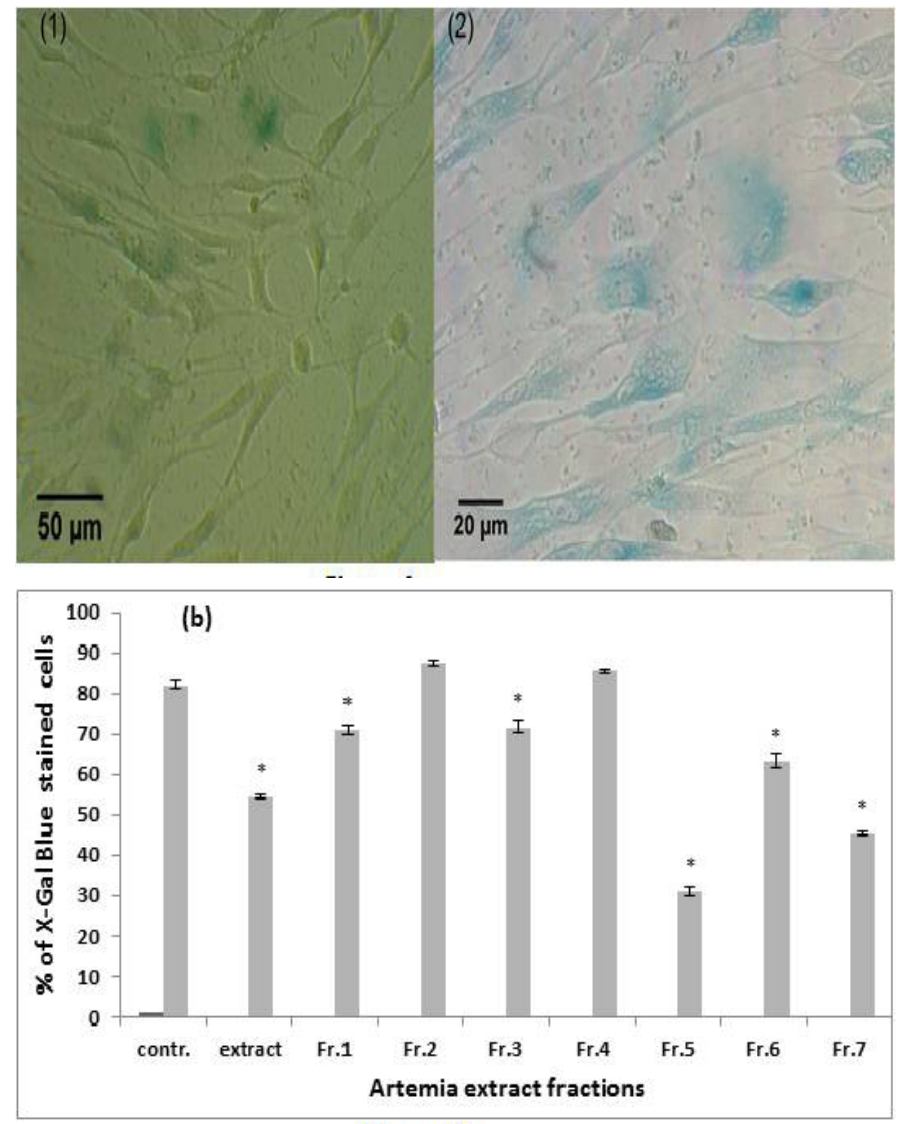

Figure 4: Cytochemical staining for acidic senescence associated $\beta$-Galactosidase (SA- $\beta$-gal. Treated cells by $\mathrm{H}_{2} \mathrm{O}_{2}$ and/or Artemia extract were collected and stained by $\mathrm{X}-\mathrm{Gal}$ as described in "Materials and Methods". The absolute of blue stained cells was observed directly by light microscopy and percent of stained cells were counted in minimum of 300 cells. a) Light microscopy figures of $\beta$-Galactosidase staining blue stained cells 1 ) low senescence cells $(250 \mathrm{X}) 2$ ) high senescence cells. $(400 \mathrm{X})$ b) Percent of $\beta$-Galactosidase positive cells. The results are mean \pm S.E.M. for three separate experiments. $*$ indicated significance of results in comparison to crude extract $p$-values $<0.01$.

\section{Expression of collagen type I}

For analysis of collagen type I mRNA expression by fibroblast in response to artemia extract RT-PCR was performed by using RNA from untreated and treated cells (in stress condition with $\mathrm{H}_{2} \mathrm{O}_{2} 6.5 \mu \mathrm{M}$ ). The quantity of the target was normalized by an endogenous reference ( $\beta$-actin) relative to the calibrator (untreated cells). This method revealed the expression of collagen type I mRNA, as defined by a 360bp PCR product in the fibroblasts. Control cells (untreated cells) showed weak expression of collagen (Figure 5a). The results showed that artemia extract treatment increased collagen synthesis in compared with un- treated control cells. The highest collagen mRNA expression was observed in cells which treated by fractions 1,5,6 and 7. The collagen mRNA level was quantified by house/keeping gene as described in methods. The results were shown in figure $5 \mathrm{~b}$. The results indicateto increase of collagen expression in cells which treated by fractions 1,5,6 and 7in comparison with untreated and house/keeping gene ( $\beta$-actin) mRNA level. As shown the percent of collagen type I expression to $\beta$-actin was $0.3,2.19$, 0.42 , and 1.31 fold in cells which treated by fractions $1,5,6$ and 7.
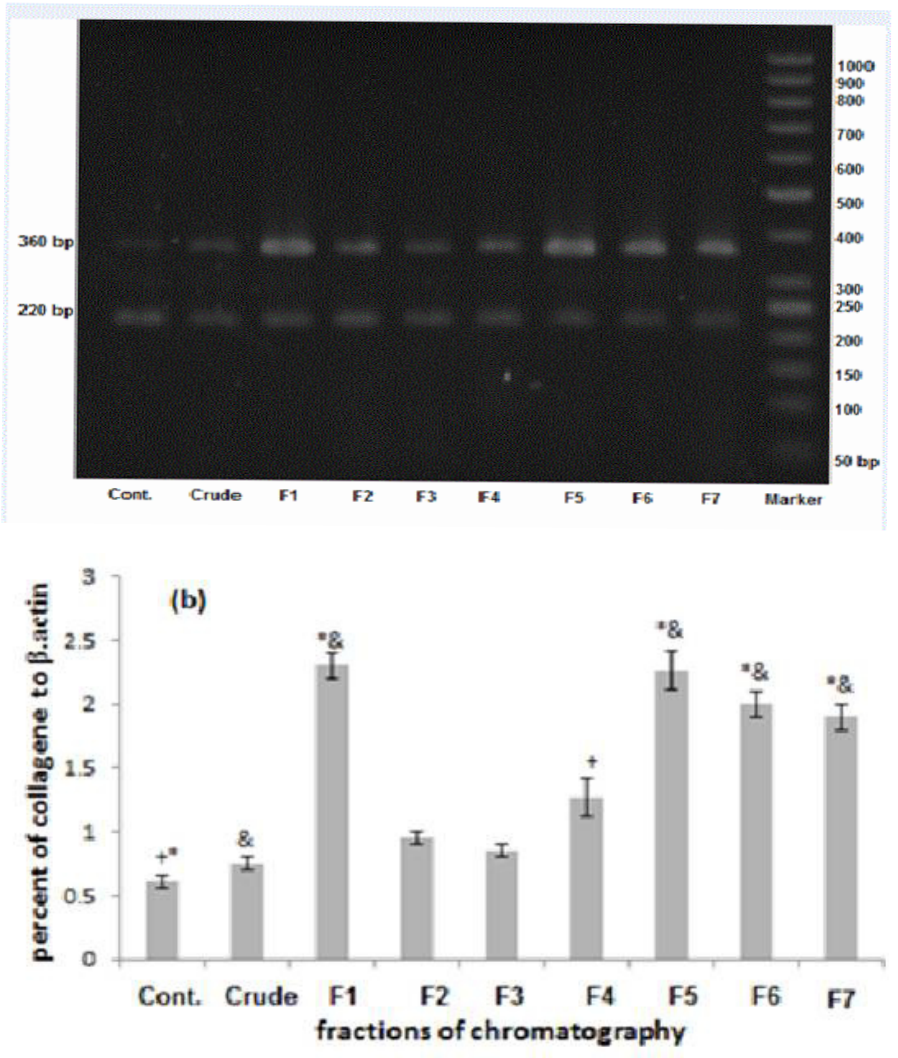

Figure 5: Changes in collagen type I gene expression of human fibroblast after treatment by artemia extract. The cells were stressed by $\mathrm{H}_{2} \mathrm{O}_{2}$ for $2 \mathrm{~h}$ and then incubated in presence and absence of artemia extract for $72 \mathrm{~h}$ as described in "Materials and Methods". Total RNA was extracted from untreated and treated cells and analyzed by RT-PCR for collagen type I gene expression. $\beta$-Actin was served as an internal house keeping gene control. a) Gel electrophoresis of RT-PCR products from untreated and treated cells by crude extract and fractions 1-7. DNA MW marker by 50 and $100 \mathrm{bp} .4 \mathrm{~b})$ Calculated percent of RT-PCR products of the collagen type I expression to $\beta$-actin of the above gel electrophoresis. $\&, *$ indicated to the significance of the fractions 1,6 and 7 in comparison to untreated control cells and cells treated by crude extract $(p<0.01)$. + indicated to the significance of the Fraction 4 in comparison to untreated control cells $(p<0.05)$.

\section{Discussion}

This study was focused on attempting to understand the effect of the artemia extract in stress condition on the cell proliferation of fibroblast cells. We have treated the fibroblast cells with artemia extract in stress condition for $72 \mathrm{hr}$. A significant behavior was observed on the cell proliferation after treatment of cells by fractions $3,4,5,6,7$.

Fibroblasts (the most common cells of connective tissue) are type of cells that synthesizes the extracellular matrix contents specially collagens, as the structural framework (stroma) in ani- 
mal tissues. They plays a critical role in wound healing. Collagen is the main structural protein of the various connective tissues in animals. Changes in protein structure during aging altered the morphology and structure of the skin as wrinkles, loss of elasticity and stiffness. The researches in the field of aging and anti-aging indicated that, stress with $\mathrm{H} 2 \mathrm{O} 2$ have a variety of effects on growth and other cellular and biochemical characteristics of normal human skin fibroblasts. H2O2in mild stress induces oxidative damage of DNA, lipids peroxidation, Reactive Oxygen Species (ROS) levels and antioxidant enzymes activity in orbital fibroblasts. The response of cells to this mild stress is the activation of one or more Stress Response (SR) pathways and stimulation of repair mechanisms consequently [6]. Our result indicated that some of artemia extract fractions can neutralize the oxidative damage of $\mathrm{H}_{2} \mathrm{O}_{2}$ in fibroblast by stimulation of collagen type I expression. In this research we found that artemia extract and its, partially purified protein fractions have antiaging effects as stimulation of the cell proliferation by fractions $3,4,5,6,7$ and anti-senescence effects offraction 5,7. These effects accompanied by stimulation of the collage type I expression in treated cells by fractions $1,5,6,7$.

Skin care cosmetic is one of the first successful products development which contain artemia extract as ingredient. Our results showed that the artemia extract had anti-aging and renewing effects on collagen. We can probably suppose that the existence and use of it in cosmetic product have anti-aging factor beside energy sources. Artemia extract induces Hsp70 in human cells and enhances cell protection from stress. Rattan et al. have reviewed a new multifunctional and compatible antiaging cosmetic ingredient from marine extract. The ingredient is obtained from zooplankton, specifically the species Artemia salina. The main component of artemia extract is diguanosine tetraphosphate (GppppG) [11]. This is known as the source of energy for Artemia salina to develop the protective capacity against environmental stress. As a cosmetic ingredient, this extract can probably boost the generation of the Extra Cellular Matrix (ECM) proteins and cyclic 3', 5'-adenosine monophosphate (cAMP). In effect, artemia extract boosts the effects of other anti-aging agents.

\section{Conclusions}

Mud of the Urmia lake and Artmia extract from there have been used in traditional treatment of inflammatory skin disorder. From the last decade to now it uses in cosmetic and health industries. The mechanism of action was not clearly understood. Our in vitro result by partially purified artemia extract proteins showed that some of fractions can induce cell proliferation of human skin fibroblasts, inhibit cell senecense and stimulate collagen type I expression.

\section{Acknowledgements}

This study was supported by the National Institute of Genetic Engineering and Biotechnology, Tehran-Iran (Grant No. 442).

\section{Ethical approval}

The study protocol was approved by the Research Ethics Committee at National institute of Genetic Engineering and Biotechnology (Tehran-Iran).

\section{Informed consent}

Primary human fibroblasts cells were isolated from human neonatal foreskins by inform and consenting donors. As the do- nors were neonates, written, informed consent was obtained from the legally authorized parents of the donor neonates for using foreskin surgery tissues prior to the study.

\section{References}

1. Saldanha SN, Royston KJ, Udayakumar N, Tollefsbol TO. Epigenetic Regulation of Epidermal Stem Cell Biomarkers and Their Role in Wound Healing. Int J Mol Sci. 2015; 17: E16.

2. Castro-Chavira SA, Fernández T, Nicolini H, Diaz-Cintra S, PradoAlcalá RA. Genetic Markers in Biological Fluids for Aging-Related Major Neurocognitive Disorder. Curr Alzheimer Res. 2015; 12: 200-209.

3. de Jesus BB, Vera E, Schneeberger K, Tejera AM, Ayuso E, et al. Telomerase gene therapy in adult and old mice delays aging and increases longevity without increasing cancer. EMBO molecular medicine. 2012: 4: 691-704.

4. GallicchioL, Miller SR, Kiefer J, Greene T, Zacur HA, et al. The Associations Between Body Mass Index, Smoking, and Alcohol Intake with Ovarian Volume in Midlife Women. Journal of Women's Health. 2015; 25: 409-415.

5. Schultz MB, Sinclair DA. When stem cells grow old: phenotypes and mechanisms of stem cell aging. Development. 2016; 143: 3-14.

6. Quan Y, WangN, Chen $Q$, Xu J, Cheng W, et al. SIRT3 inhibits prostate cancer by destabilizing oncoprotein c-MYC through regulation of the PI3K/Akt pathway. Oncotarget. 2015; 6: 2649426507.

7. AneirosA, Garateix A. Bioactive peptides from marine sources: pharmacological properties and isolation procedures. Journal of Chromatography. 2004; 803: 41-53.

8. Wilson-Sanchez G, Moreno-Félix C, Velazquez C, PlascenciaJatomea M, Acosta A, et al. Antimutagenicity and antiproliferative studies of lipidic extracts from white shrimp (Litopenaeusvannamei). Marine drugs. 2010; 8: 2795-2809.

9. JimenoJ, Faircloth G, Sousa-FaroJ M, Scheuer P, Rinehart K. New Marine Derived Anticancer Therapeutics- A Journey from the Sea to Clinical Trials. Marine Drugs. 2004; 2: 14-29.

10. Park S, Yang MJ, Ha SN, Lee JS. Effective Anti-aging Strategies in an Era of Super-aging. J Menopausal Med. 2014; 20: 85-89.

11. Rattan SI, Kryzch V, Schnebert S, Perrier E, Nizard C. Hormesisbased anti-aging products: a case study of a novel cosmetic. Dose-Response. 2013; 11: 99-108.

12. Schagen SK, Zampeli VA, Makrantonaki E, Zouboulis CC. Discovering the link between nutrition and skin aging. Dermatoendocrinology. 2012; 4: 298-307.

13. Liang $\mathrm{P}, \mathrm{Amons} \mathrm{R}, \mathrm{MacRae} \mathrm{TH}$, Clegg JS. Purification, structure and in vitro molecular-chaperone activity of Artemia p26, a small heat shock/ $\alpha$-crystalline protein. Eur J Biochem . 1997; 243: 225-232.

14. Timms B. A review of the biology of Australian halophilic anostracans (Branchiopoda: Anostraca). Journal of Biological Research-Thessaloniki. 2014; 21: 213-226.

15. Kelts K, Shahrabi M. Holocene sedimentology of hypersaline Lake Urmia, northwestern Iran. Palaeogeography, Palaeoclimatology, Palaeoecology. 1986; 54: 105-130.

16. Eimanifar A, Mohebbi F. Urmia Lake (northwest Iran): A brief review. Saline systems. 2007; 3: 1-8.

17. Discover Persia. Orumiyeh (Urmia) Lake + History \& Treatment. 2018. 
18. Rotini A, Manfra, Canepa S, Tornambè A, Migliore L. Can Artemia Hatching Assay Be a (Sensitive) Alternative Tool to Acute Toxicity Test?. Bulletin of Environmental Contamination and Toxicology. 2015; 95: 745-751.

19. Moreno A, Mendez R, DeHaro C. Characterization of cell-free protein-synthesis systems from undeveloped and developing Artemia embryos. Biochem. 1991; J276: 809-816.

20. Ernst $\mathrm{O}$, Zor T. Linearization of the Bradford protein assay. J Vis Exp. 2010; p: 1918.

21. Brunelle JL, Green R. One-dimensional SDS-polyacrylamide gel electrophoresis (1D SDS-PAGE). Methods in enzymology. 2013; 541: 151-159.

22. Gary RK, KindellSM. Quantitative assay of senescence-associated $\beta$-galactosidase activity in mammalian cell extracts. Analytical biochemistry. 2015; 343: 329-334. 